\title{
Comparative Evaluation of Antifungal and Antibacterial Activities of Crude Extracts of Pleurotus sajor-caju, Pleurotus tuber-regium and Lentinus squarrosulus (Basidiomycota, Pleurotaceae, Lentinaceae) from Cameroon
}

Dominique Claude Mossebo, Blondo-Pascal Metsebing, Romuald Oba, Fabrice Tsigaing Tsigain, Leif Ryvarden, Thierry Youmbi Fonkui, Charlotte Mungoh Tata, Derek Tantoh Ndinteh

\section{ABSTRACT}

Antifungal and antibacterial activities of crude extracts of 3 tropical mushrooms including Pleurotus sajor-caju, Pleurotus tuber-regium and Lentinus squarrosulus were investigated on eleven species of bacterial and three of fungal human pathogens. For the pathogenic fungi, the Minimal Inhibitory Concentration (MIC) of carpophore extracts ranged from 0.39 $\mathrm{mg} / \mathrm{mL}$ to $6.25 \mathrm{mg} / \mathrm{mL}$ for Candida albicans, $0.78 \mathrm{mg} / \mathrm{mL}$ to $6.25 \mathrm{mg} / \mathrm{mL}$ for Aspergillus fumigetus, and $1.56 \mathrm{mg} / \mathrm{mL}$ to $6.25 \mathrm{mg} / \mathrm{mL}$ for Aspergillus ochraceus. For bacteria, the MIC values ranged from $6.25 \mathrm{mg} / \mathrm{mL}$ to 12.5 $\mathrm{mg} / \mathrm{mL}$ on most Gram positive strains including Bacillus subtilis, Enterococcus faecalis, Staphylococcus aureus and Mycobacterium smegmatis. This MIC value was the same $(12.5 \mathrm{mg} / \mathrm{mL})$ for the 3 crude extracts tested on Staphylococcus epidermidis for the Gram positive strains. Gram negative bacteria were generally less sensitive to crude extracts with higher MIC values ranging from $6.25 \mathrm{mg} / \mathrm{mL}$ to $12.5 \mathrm{mg} / \mathrm{mL}$ for Escherichia coli and Enterobacter cloacae and the same $(12.5 \mathrm{mg} / \mathrm{mL})$ for Proteus vulgaris, Klebsiella oxytoca, Klebsiella aerogenes and Proteus mirabilis. Based on the above mentioned figures, it appears that strains of pathogenic fungi tested are generally much more sensitive to crude extracts than strains of bacteria. In fact, antimicrobial activities of the 3 crude extracts tested are stronger on human pathogenic fungi than bacteria. These results are evidence that carpophores of the 3 mushrooms species could be a source of new molecules potentially more effective than synthetic products against some human pathogenic fungi and bacteria.

Keywords: Medicinal mushrooms, Pleurotus spp., Lentinus spp., antifungal and antibacterial activities, Minimal Inhibitory Concentration.
Published Online: October 27, 2020

ISSN: 2684-5199

DOI : 10.24018 /ejbio.2020.1.5.97

Dominique Claude Mossebo *

Mycological Laboratory, University of

Yaoundé 1, Cameroon.

(e-mail: dmossebo@yahoo.fr)

Blondo-Pascal Metsebing

Mycological Laboratory, University of

Yaoundé 1, Cameroon.

(e-mail: bmetsebing@yahoo.com)

Romuald Oba

Mycological Laboratory, University of Yaoundé 1, Cameroon.

(e-mail: romuald_oba@yahoo.fr)

Fabrice Tsigaing Tsigaing

Mycological Laboratory, University of

Yaoundé 1, Cameroon.

(e-mail: ftsigaing@yahoo.fr)

Leif Ryvarden

Institute of Biological Sciences,

University of Oslo, Norway.

(e-mail: leif.ryvarden@ibv.uio.no)

Thierry Youmbi Fonkui

Department of Biotechnology and Food

Technology, University of Johannesburg,

South Africa.

(e-mail: thierryfy@uj.ac.za)

Charlotte Mungoh Tata

Department of Chemical Sciences, University of Johannesburg, South Africa.

(e-mail: ttcharlym@yahoo.com)

Derek Tantoh Ndinteh

Department of Chemical Sciences,

University of Johannesburg, South Africa.

(e-mail: dndinteh@uj.ac.za)

*Corresponding Author

\section{INTRODUCTION}

Therapeutic properties of mushrooms have been used for thousands years by populations of most parts of the world to cure numerous human diseases. Besides higher plants that have been used for millenaries and nowadays still largely used worldwide by peoples of diverse origins in the traditional pharmacopoeia to cure multiple human pathologies, numerous mushrooms species are also known to be used in traditional medicine in some parts of the world and are now reported to also contain compounds with proven efficacy on numerous human diseases. In fact, over the past three decades, several studies have shown that numerous species of mushrooms also reveal compounds in their constituents with proven medicinal and pharmaceutical properties. Besides their antifungal and antibacterial activities [1]-[5] which also stand as the main subject of this 
study, various scientific reports have been made on mushrooms numerous potential or effective healing properties as cardioprotectors, blood pressure reducers, hepatoprotectors [6]-[10], nephroprotectors [8], [10], [11], hypoglycemic agents, anti-inflammatories [8], [10], antiinfectious and anti-HIV agents, antitumoral agents and antioxydants [8]-[11]. Nowadays, in spite of the proven efficacy of most synthetic antibiotics and antifungal products on numerous human infections, microbes continue to develop various levels of resistance according to the infections types and their etiology, whereby the approach of the above mentioned authors and several others to investigate other potential sources of new and more efficient compounds, physiologically beneficial and safe for the human organism [12].

Research works on medicinal properties of natural substances have so far focused essentially on green plants and very little on mushrooms. Over an estimated potential of more than 145000 mushrooms species of which just about $10 \%(\approx 14500$ species $)$ described and only about 2500 edible or with medicinal properties [13], very few have so far been investigated for their genuine pharmaceutical potential. Field works in the tropics have shown that mushrooms including Agaricales and Polyporales are numerous and diversified in the tropical rain forests of Africa where they are estimated in thousands, but very few have been reported in published scientific papers [14]-[17] ] and are mostly cited rather for their various uses in African traditional pharmacopoeia [18]-[20]. The largest part of tropical Macromycetes from Africa remains uninvestigated and therefore constitutes an enormous potential where new more efficient compounds could be identified and exploited to solve the increasing problems of disease resistance to current medicines. This research work in line with the above mentioned goals aimed at assessing the antimicrobial activities of crude extracts of 3 mushrooms of which 2 Agaricales of the family of Pleurotaceae including $P$. tuber-regium (Fig. 1) and P. sajor-caju (Fig. 2) and one Polyporale of the family of Lentinaceae which is L. squarrosulus (Fig. 3). These 3 higher Basidiomycetes are common in tropical and central Africa and parts of Asia. L. squarrosulus and P. sajor-caju grow on live and dead wood on which they cause white rot and $P$. tuber-regium grows only on a self-prefabricated substrate in the soil called sclerotium (Fig. 1 left) resembling to yams or cocoyams tubers. According to existing literature [18]-[20], these 3 species are reported to be used in African traditional pharmacopoeia to cure several diseases. This study therefore aims at assessing comparatively and for the first time the crude extracts of carpophores of the 3 mushrooms species in order to determine whether they could be considered as new sources of potentially more efficient antifungal and antibacterial compounds.
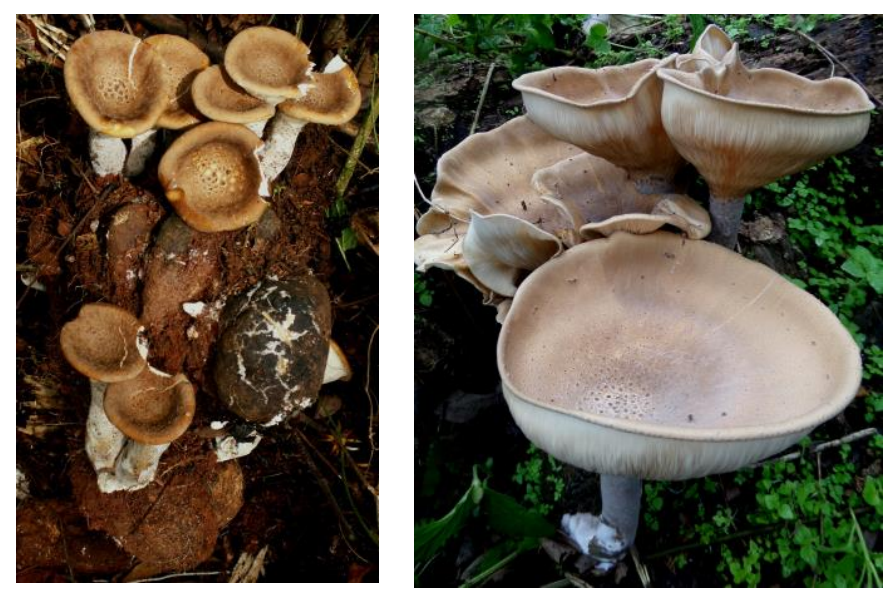

Fig. 1. Pleurotus tuber-regium (HUY1-DM 563A) on sclerotia (left).

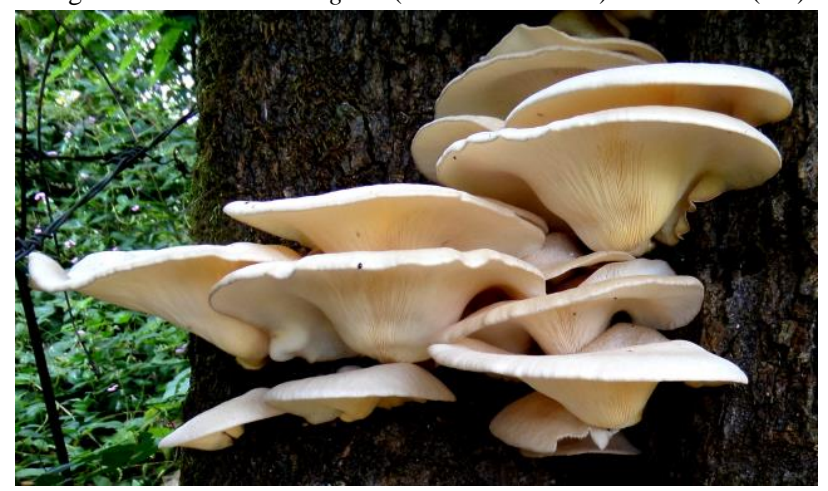

Fig. 2. Pleurotus sajor-caju (HUY1-DM 1150) on a tree trunk.

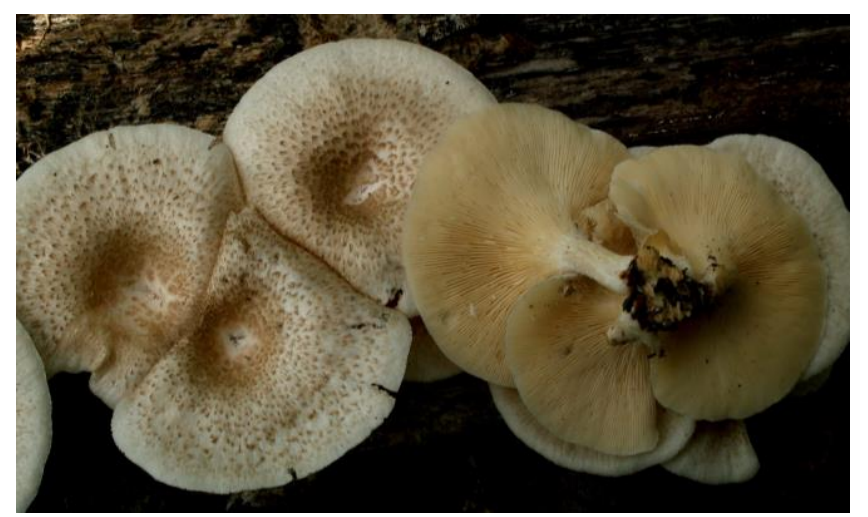

Fig. 3. Lentinus squarrosulus (HUY1-DM 920) on decaying wood.

\section{MAterials And Methods}

\section{A. Materials}

\section{Fungal samples and extraction}

Fungal material was made of pieces of carpophores of the three mushrooms species (Figs. 1, 2, 3), all collected in the forests of the Centre, South and Eastern regions of Cameroon, dried and conserved in the Mycological Herbarium of the Faculty of science of the University of Yaoundé 1 under the number HUY1-DM 1150, HUY1-DM 563A and HUY1-DM 920 respectively for P. sajor-caju, $P$. tuber-regium and L. squarrosulus. They were first cleaned of impurities and cut or broken into small pieces using a knife before being powdered separately in an electric blender. The powder obtained was thereafter conserved in plastic bags labelled with their species names and herbarium numbers. 


\section{Test Microorganisms}

Eleven strains of bacteria were tested, all furnished by Sigma Aldrich, South Africa branch. These strains included five Gram positive [Bacillus subtilis (ATCC 19659), Enterococcus faecalis (ATCC 13047), Staphylococcus epidermidis (ATCC 14990), Staphylococcus aureus (ATCC 25923), Mycobacterium smegmatis (ATCC 2155)] and six Gram negative [Enterobacter cloacae (ATCC 13047), Proteus vulgaris (ATCC 6380), Klebsiella oxytoca (ATCC 8724), Klebsiella aerogenes (ATCC 13048), Proteus mirabilis (ATCC 7002) and Escherichia coli (ATCC 25922)] pathogenic bacteria.

Three strains of human pathogenic fungi including Candida albicans, Aspergillus fumigatus and Aspergillus ochraceus were tested, all originally isolated in pure culture and certified as such by the Mycotoxins Laboratory, Department of Biotechnology and Food Technology of the University of Johannesburg. The three strains registration process is still ongoing.

\section{B. Methods}

\section{Extraction of crude natural substances}

Crude extracts of mushrooms were obtained according to the method described by Boonsong and Klaypradit [21] with slight modifications. Freshly collected mushrooms carpophores were first dried at mild temperature $\left(50{ }^{\circ} \mathrm{C}\right.$ $60{ }^{\circ} \mathrm{C}$ ) using a DÖRREX electric dryer and samples intended for extraction were selected from the dried material and milled to powder before extraction using hexane (least polar) and chloroform (more polar) as solvents. $400 \mathrm{~mL}$ of hexane or chloroform were added to 5 $\mathrm{g}$ of powder, stirred each for 24 hours and filtered using Whatman No. 4 filter paper. The filtrate was evaporated at $40^{\circ} \mathrm{C}$ using a rotary-evaporator. $0.05 \mathrm{~g}$ of each of both extracts were mixed to give $0.1 \mathrm{~g}$ hexane : chloroform $(1: 1)$ extract that was used for antimicrobial assay, the aim of mixing both extracts being to bring together all polar and apolar constituents of the mushroom extracts for more efficiency during antimicrobial assays. 3 similar crude extracts mixtures were done at the same proportion (1:1) for each mushroom species to constitute 3 replicates that were tested differently in 3 antimicrobial assays and their mean MIC values recorded.

\section{Preparation of bacterial and fungal suspensions}

The test bacterial and fungal suspensions were prepared to the concentration of $1 \times 10^{5}$ bacteria/mL according to McFarland [22] and $1 \times 10^{5}$ spores/mL respectively. Bacteria and fungi strains were grown each in triplicate (3 repetitions) as well, the bacteria in nutrient broth at $37{ }^{\circ} \mathrm{C}$ for $12-16 \mathrm{hrs}$ and fungi on RPMI 1640 medium at $30^{\circ} \mathrm{C}$ for $24 \mathrm{~h}$. Spores were thereafter dipped into the Ringer's solution, the role of which was to stabilize them by temporally inhibiting their germination. The spores' suspension was prepared $24 \mathrm{hrs}$ before the tests and kept at $4{ }^{\circ} \mathrm{C}-8{ }^{\circ} \mathrm{C}$ in the refrigerator.

\section{Determination of the Minimal Inhibitory Concentration (MIC)}

The MIC was determined by microdilution according to Eloff [23] with slight modifications. Nutrient Broth culture medium was used for bacteria and RPMI 1640 medium for pathogenic fungi. Briefly, $100 \mu \mathrm{L}$ aliquots of culture suspension were dispensed into each of the 96 microwells test-plate (Fig. 4), then $100 \mu \mathrm{L}$ of $25 \mathrm{mg} / \mathrm{mL}$ extract solution dissolved in DMSO $(25 \mathrm{mg} / \mathrm{mL}$ or $100 \mathrm{mg}$ in $4 \mathrm{~mL}$ DMSO) were added to line B, column 2 to 11 (Fig. 4). Serial dilutions were successively realized from line $B$ to $G$ by mixing suspension of line $\mathrm{B}$ and pipetting $100 \mu \mathrm{L}$ in wells of line $C$ which were also mixed and $100 \mu \mathrm{L}$ pipetted in wells of line D and so on and so forth until wells of line $F$ were pipetted into those of line G. $100 \mu \mathrm{L}$ of mixture was thereafter pipetted out of each well of line G. In this process, the concentration of the mixture in the wells of each line from B to $\mathrm{G}$ (Fig. 4) is that of the preceding line divided by two and by so doing, six test concentrations $(12.5 \mathrm{mg} / \mathrm{mL}, 6.25 \mathrm{mg} / \mathrm{mL}, 3.13 \mathrm{mg} / \mathrm{mL}, 1.56 \mathrm{mg} / \mathrm{mL}, 0.78$ $\mathrm{mg} / \mathrm{mL}, 0.39 \mathrm{mg} / \mathrm{mL}$ ) were realized according to Maragesi et al. [24]. Wells of line A (A1 to A12) and H (H1 to H12) and columns 1 to 12 (1A to $1 \mathrm{H}$ and $12 \mathrm{~A}$ to $12 \mathrm{H}$ ) were set as positive and negative controls respectively. The positive control was inoculated with bacterial or fungal suspension only, while only DMSO was added to the negative control wells. Aliquots $(100 \mu \mathrm{L})$ of each bacterial or fungal suspension were inoculated into the wells to obtain a final volume of $200 \mu \mathrm{L}$ in each well of the plate. The plates were sealed and incubated at $37{ }^{\circ} \mathrm{C}$ for $24 \mathrm{hrs}$ for bacteria and 72-84 hrs for fungi at the same temperature. In order to visualize the concentrations showing bactericidal or fungicidal effect in the plates, $10 \mu \mathrm{L}$ of 2-(4-iodophény)-3(4-nitrophenyl)-5-phenyltetrazolium chloride (INT) $2 \mathrm{mg} / \mathrm{mL}$ was added to each of the 96 wells and incubated at $37{ }^{\circ} \mathrm{C}$ for 1 to $5 \mathrm{hrs}$ for bacterial test and 1 to 2 (sometimes until 7) days for fungal test still at $37{ }^{\circ} \mathrm{C}[25]-$ [27].

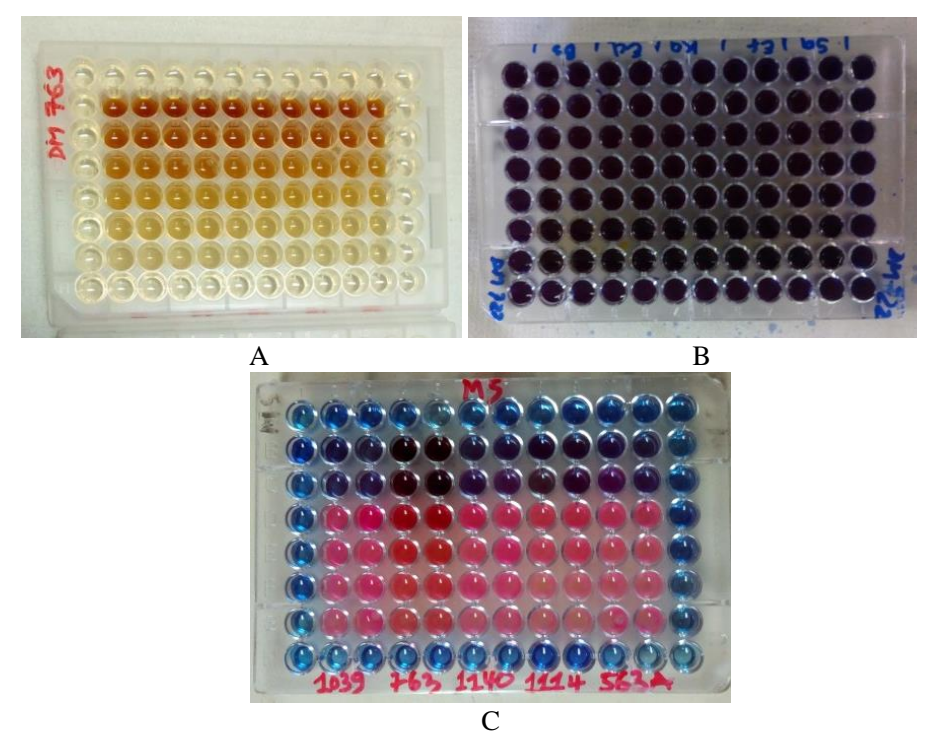

Fig. 4. Antibacterial and antifungal tests on the 96 microwells plate. A. Plate with wells containing crude extracts at various concentrations and suspensions of bacteria or fungi. B. Plate after pipetting drops of the INTdye in the wells. C. Plate ready for reading the MIC values after reaction of the INT-dye with microorganisms suspensions in the wells. Plate $\mathbf{A} / \mathbf{B} / \mathbf{C}$. Positive control wells: A1 to A12 and H1 to H12; Negative control wells: $1 \mathrm{~A}$ to $1 \mathrm{H}$ and $12 \mathrm{~A}$ to $12 \mathrm{H}$.

After incubation, the plates were visualized for MIC determination by spotting the concentration line were colour change occurred. In fact, wells with bacteria and fungi still alive turned pink (Fig. 4/C) due to reaction of 
their metabolism products with INT-dye, whereas in wells where the crude extracts concentrations inhibited their growth, the original colour of the crude extract remained unchanged.

\section{RESUlts}

MIC values (Table 1, 2 and Figs. 5, 6) recorded are the mean values of the 3 replicates monitored for each antimicrobial test. These values show that in general, antimicrobial activity of crude extracts of carpophores of the 3 mushrooms species is much higher on pathogenic fungi than bacteria. In fact, the MIC values range from 0.39 to $6.25 \mathrm{mg} / \mathrm{mL}$ in pathogenic fungi and from 6.25 to 12.5 $\mathrm{mg} / \mathrm{mL}$ in bacteria, thereby showing a higher sensitiveness of pathogenic fungi to crude extracts than bacteria.
About bacteria (Table 1 and Fig. 5), be they Gram + or -, considering the MIC values recorded, they are generally less sensitive to the same crude extracts compared to pathogenic fungi with MIC ranging here from 6.25 to 12.5 $\mathrm{mg} / \mathrm{mL}$ and average values from 8.33 to $10.41 \mathrm{mg} / \mathrm{mL}$ and up to $12.5 \mathrm{mg} / \mathrm{mL}$ for some of the 11 strains of bacteria tested. The MIC values recorded here also show that Gram + bacteria are generally more sensitive to the 3 crude extracts with the lowest average MIC of $8.33 \mathrm{mg} / \mathrm{mL}$ for 2 strains and $10.41 \mathrm{mg} / \mathrm{mL}$ for 2 other strains (Table 1), whereas the average values for the 6 Gram - strains range from $10.41 \mathrm{mg} / \mathrm{mL}$ for 2 strains to $12.5 \mathrm{mg} / \mathrm{mL}$ for 4 of the 6 strains (Table 1) tested.

TABle 1: Minimal Inhibition Concentration (Mic) OF Crude Extracts Of Carpophores Of PleuRotus SAJOR-CAJU, PLEUROTUS TUBER-REGIUM AND LENTINUS SQUARROSULUS AGAINST HUMAN PATHOGENIC BACTERIA

\begin{tabular}{|c|c|c|c|c|c|c|c|c|c|c|c|}
\hline \multicolumn{12}{|c|}{ Minimal Inhibition Concentration (MIC, mg/mL) } \\
\hline & \multicolumn{5}{|c|}{ Gram positive $(+)$ bacteria } & \multicolumn{6}{|c|}{ Gram negative (-) bacteria } \\
\hline & $B S$ & $E F$ & $S E$ & $S A$ & $M S$ & $E C L$ & $P V$ & $K O$ & $K A$ & $P M$ & $E C$ \\
\hline P. sajor-caju & 12.5 & 6.25 & 12.5 & 6.25 & 6.25 & 12.5 & 12.5 & 12.5 & 12.5 & 12.5 & 12.5 \\
\hline P. tuber-regium & 12.5 & 12.5 & 12.5 & 6.25 & 6.25 & 12.5 & 12.5 & 12.5 & 12.5 & 12.5 & 6.25 \\
\hline L. squarrosulus & 6.25 & 12.5 & 12.5 & 12.5 & 12.5 & 6.25 & 12.5 & 12.5 & 12.5 & 12.5 & 12.5 \\
\hline $\begin{array}{l}\text { Average MIC } \\
\text { value for the } \\
\text { bacteria strain }\end{array}$ & 10.41 & 10.41 & 12.5 & 8.33 & 8.33 & 10.41 & 12.5 & 12.5 & 12.5 & 12.5 & 10.41 \\
\hline
\end{tabular}

BS: Bacillus subtilis; EF: Enterococcus faecalis; SE: Staphylococcus epidermidis; SA: Staphylococcus aureus; MS: Mycobacterium smegmatis. ECL: Enterobacter cloacae; PV: Proteus vulgaris; KO: Klebsiella oxytoca; KA: Klebsiella aerogenes; PM: Proteus mirabilis; EC: Escherichia coli.
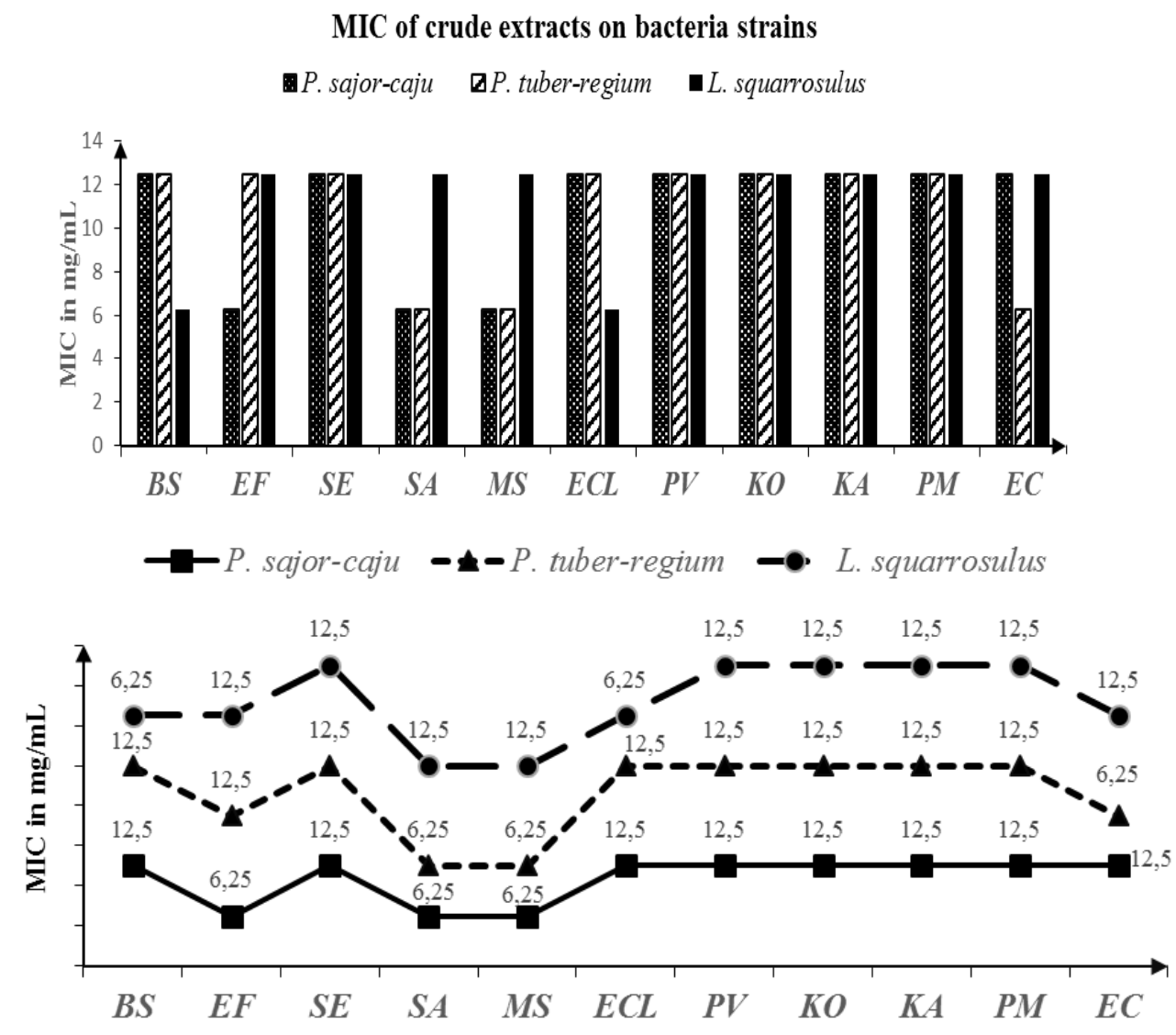

Fig. 5. Histograms and curves comparing the MIC of crude extracts of carpophores of Pleurotus sajor-caju, Pleurotus tuber-regium and Lentinus squarrosulus on 11 strains of human pathogenic bacteria. 
Concerning pathogenic fungi (Table 2, Fig. 6) and particularly Candida albicans, the MIC values range from 0.39 to $6.25 \mathrm{mg} / \mathrm{mL}$ for the crude extracts of the 3 mushrooms with an average value of $3.25 \mathrm{mg} / \mathrm{mL}$ on this pathogenic yeast which appears to be more sensitive to crude extracts of Pleurotus sajor-caju $(\mathrm{MIC}=0.39 \mathrm{mg} / \mathrm{mL})$ among the 3 tested. On Aspergillus fumigetus, MIC values range from 0.78 to $6.25 \mathrm{mg} / \mathrm{mL}$ with an average of 3.38 $\mathrm{mg} / \mathrm{mL}$ for the 3 crude extracts tested. These MIC values show that Aspergillus fumigetus is more sensitive (MIC = $0.78 \mathrm{mg} / \mathrm{mL}$ ) to crude extracts of Lentinus squarrosulus and far less (MIC $=6.25 \mathrm{mg} / \mathrm{mL}$ ) to that of Pleurotus tuberregium. With MIC values ranging from 1.56 to $6.25 \mathrm{mg} / \mathrm{mL}$ and an average value of $4.68 \mathrm{mg} / \mathrm{mL}$, Aspergillus ochraceus appears as the less sensitive pathogenic fungus to the 3 tested crude extracts.

TABle 2: Minimal InHibition CONCENTRATION (MiC) OF CRUdE EXTRACTS OF CARPOPHORES OF PLEUROTUS SAJOR-CAJU, PLEUROTUS TUBER-REGIUM AND LENTINUS SQUARROSULUS AGAINST HUMAN PATHOGENIC FUNGI

\begin{tabular}{lccc}
\hline \multicolumn{4}{c}{ PATHOGENIC FUNGI } \\
\hline & \multicolumn{3}{c}{ Human pathogenic fungi } \\
\cline { 2 - 4 } & $\begin{array}{c}\text { Candida } \\
\text { albicans }\end{array}$ & $\begin{array}{c}\text { Aspergillus } \\
\text { fumigetus }\end{array}$ & $\begin{array}{c}\text { Aspergillus } \\
\text { ochraceus }\end{array}$ \\
\cline { 2 - 4 } $\boldsymbol{P}$ sajor-caju & 0.39 & 3.13 & 6.25 \\
$\boldsymbol{P}$. tuber-regium & 6.25 & 6.25 & 6.25 \\
$\boldsymbol{L}$. squarrosulus & 3.13 & 0.78 & 1.56 \\
\hline Average MIC value for & 3.25 & 3.38 & 4.68 \\
the pathogenic fungus & & &
\end{tabular}

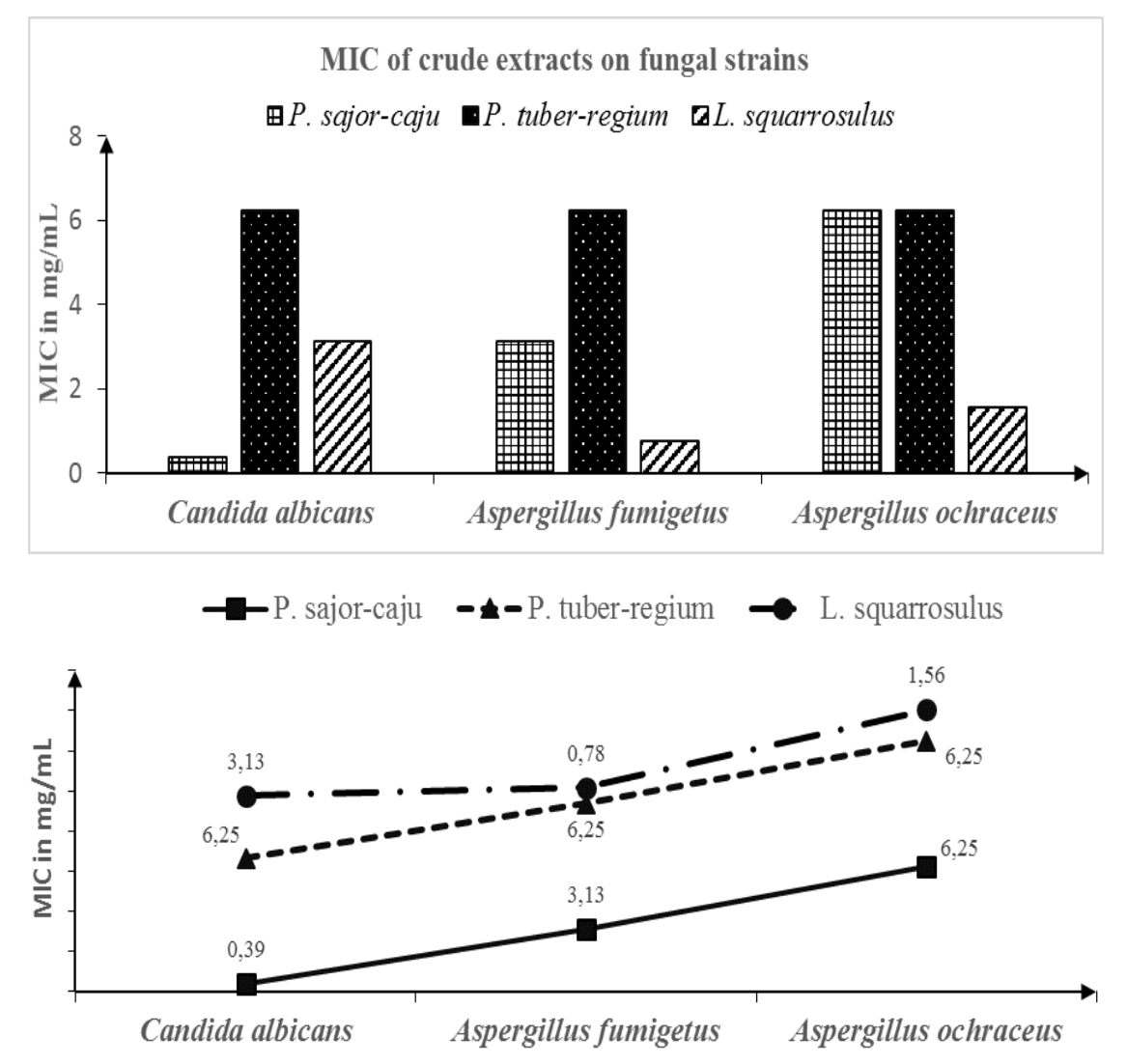

Fig. 6. Histograms and curves comparing the MIC of crude extracts of carpophores of Pleurotus sajor-caju, Pleurotus tuber-regium and Lentinus squarrosulus on 3 strains of human pathogenic fungi.

\section{DISCUSSION}

According to Algiannis et al. [28], the efficiency of antimicrobial activities of the crude extracts could be assessed according to the MIC values recorded. According to the author, species with MIC values lower than 0.5 $\mathrm{mg} / \mathrm{mL}$ are strong inhibitors, those with values between 0.6 $1.5 \mathrm{mg} / \mathrm{mL}$ are moderate inhibitors and MIC values higher than $1.6 \mathrm{mg} / \mathrm{mL}$ are weak inhibitors.

Compared to the MIC figures recorded (Table 1 and 2) and concerning particularly pathogenic fungi (Table 2), crude extracts of Pleurotus sajor-caju appears as the lone strong inhibitor (MIC $=0.39 \mathrm{mg} / \mathrm{mL}$ ) on Candida albicans among all the extracts tested. Then follows as moderate inhibitors the crude extracts of Lentinus squarrosulus on Aspergillus fumigetus and that of the same species on
Aspergillus ochraceus with respectively MIC values of 0.78 and $1.56 \mathrm{mg} / \mathrm{mL}$. All other crude extracts tested stand as weak inhibitors of the 3 pathogenic fungi according to the MIC values recorded (Table 2).

About bacteria, crude extracts of the 3 mushrooms appear all as weak inhibitors of the 11 strains of bacteria with MIC values (Table 1) ranging from $6.25 \mathrm{mg} / \mathrm{mL}$ to $12.5 \mathrm{mg} / \mathrm{mL}$.

In a similar study of antibacterial and antifungal activities of selected wild mushrooms using as well as MIC values for assessment, Chelela et al. [14] included besides crude extracts of mushrooms, Gentamycin and Fluconazole as positive control for antibacterial and antifungal activities tests respectively. The MIC values recorded by the authors ranged from 0.0015 to $0.0061 \mathrm{mg} / \mathrm{mL}$ for Gentamycin according to the pathogenic bacteria and from 0.003 to $0.006 \mathrm{mg} / \mathrm{mL}$ according to the pathogenic fungi. Referred to 
the scale of Algiannis et al. [28], these synthetic antibacterial and antifungal agents could be ranked as very strong inhibitors compared to the tested mushrooms representing rather weak inhibitors at tested concentrations.

Johnsy and Kaviyarasan [29] studied the antimicrobial activities of various concentrations of methanolic and water extract of Lentinus (Pleurotus) sajor-caju on 6 strains of bacteria including Bacillus subtilis, Micrococcus luteus, Staphylococcus aureus, Escherichia coli, Pseudomonas aeruginosa, Salmonella typhi and the yeast Candida albicans. Even though assessment here was not based on MIC values, but rather on the zone of inhibition in the culture plates, results obtained by both authors showed that methanol extract effectively inhibited $P$. aeruginosa, $M$. luteus, Salmonella typhi and C. albicans and also showed maximum inhibition zone compare to water extract. Reena et al. [30] studying the antibacterial activity of the ethanolic extract of Lentinus squarrosulus showed that this extract was active at different concentrations levels of efficacy on Staphylococcus aureus (MTCC-902), Escheriachia coli (MTCC-1599) and Salmonella typhi (MTCC-734). Even though fewer strains of bacteria and fungi were tested by Johnsy and Kaviyarasan [29] and Reena et al. [30], the results obtained are evidence that MIC values (Table 1 and 2) recorded in our antibacterial and antifungal tests could be improved by testing other solvents at varying concentrations.

Among the 3 mushrooms of which the crude extracts were tested in this study, $P$. tuber-regium is the most cited, but most often rather in the African traditional pharmacopoeia [18]-[20] as used to cure several diseases including headache, fever, stomach pain, constipation, asthma, heart diseases including throbs and high blood pressure. Guissou et al. [18] and Oyetayo [19] also mentioned that Lentinus squarrosulus is used in the African traditional pharmacopoeia to cure heart diseases and mumps. Our results show that carpophores of both mushrooms also contain compounds with antifungal and antibacterial properties. It is also worth mentioning that in the past, studies on antimicrobial activities by determination of MIC values were carried out only in very few species [14] growing in tropical Africa. The MIC values recorded in our study are similar or close to those registered in crude extracts of several other species of mushrooms [14], [31][35] and medicinal plants [36]-[38] growing in other parts of the world. In other studies using other tools of assessment, Adebayo et al. [2] and Badalyan et al. [3] already demonstrated the antagonistic antifungal activity of extracts of $P$. tuber-regium against selected fungal pathogens that were however different from those tested in our study. Considering the number of pathogenic bacteria and fungi tested here, our study stands as an important contribution to this very wide, but still very poorly investigated research field on medicinal and pharmacological potential of macroscopic fungi that are numerous and widely distributed in the tropical rain forests of Africa.

\section{CONCLUSION}

In conclusion, our results stand as a remarkable contribution in the assessment of antifungal and antibacterial activities of tropical mushrooms considering that they are until now very little investigated in this field of research. These results confirm that hexane and chloroform crude extracts of carpophores of the 3 mushrooms species contain among other molecules, compounds with antimicrobial properties against some human pathogenic fungi and bacteria. On the basis of these rather promising results, more refined studies could be envisaged in the aim to accurately identify and isolate the active compounds of the crude extracts that inhibit fungi and bacteria, the ultimate goal being to manufacture natural or new pharmaceutical products potentially more efficient against diseases caused by the tested human pathogenic bacteria and fungi including some infectious diseases as well as fungal infections such as mycosis or mycotoxicosis caused by $C$. albicans or A. fumigetus and A. ochraceus.

\section{ACKNOWLEDGEMENTS}

This work was achieved thanks to diverse contributions to whom we are highly grateful, starting by the IRD (French Research Institute for Development) who under his SEP2D ("Sud Expert Plantes Développement Durable") programme, awarded a research grant to two of the coauthors for a research stay at the University of Johannesburg in South Africa specially to carry out this research work. The corresponding author hereby also particularly thanks the SEP2D programme Executive Secretary, Mrs. Stéphanie Ardila-Chauvet for her particular attention in the follow-up of our SEP2D/PRP $N^{\circ} 5$ project under which the research work was financed. Professor Penny Govender who is heading the Department of Applied Chemistry of the University of Johannesburg in South Africa offered us all his laboratories and facilities to render this work possible. We hereby greatly thank him as well as the laboratories staff at all levels for the follow-up of the research work and technical advices given to the students during their stay in Johannesburg. We hereby also extend our thanks to the Head of Department of English at the University of Yaoundé 1 in Cameroon for kindly reading the manuscript.

\section{REFERENCES}

[1] Alves MJ, Ferreira IC, Dias J, Teixera V, Martins A, Pintado M. A review on antimicrobial activity of mushroom (Basidiomycetes) extracts and isolated compounds. Plant Medicine, 78:1707-1718, 2012.

[2] Adebayo EA, Martinez-Carrera D, Morales P. Comparative study of antioxidant and antibacterial properties of the edible mushrooms Pleurotus levis, P. ostreatus, P. pulmonarius and P. tuber-regium. International Journal of Food Sciences and Technology, 53(5):1316-1330, 2018.

[3] Badalyan SM, Isikhuemhen OS, Gharibyan NG. Antagonistic/antifungal activity of Pleurotus tuberregium (Fr.) Singer against selected fungal pathogens. International Journal of Medicinal Mushrooms, $10(2): 155-162, \quad 2008$. https://doi.org/10.1615/Int J Med Mushr.v10.i2.60.

[4] Imtiaj A, Jayasinghe C, Woo Lee G, Soo Lee T. Antibacterial and antifungal activities of Stereum ostrae, an inedible wild mushroom. 


\section{Mycobiology,}

35(4):1-10,

https://doi.org/104489/MYCO.2007.35.4.210

[5] Synytsya A, Monkai J, Bleha R, Macurkova A, Ruml T, Ahn J, Chukeatirote E. Antimicrobial activity of crude extracts prepared from fungal mycelia. Asian Pacific Journal of Tropical Biomedicine, 7:257-261, https://doi.org/10.1016/j.apjtb.2016.12.011.

[6] Biswas G, Rana S, Acharya K. Cardioprotective activity of ethanolic extract of Astraeus hygrometricus (Pers.) Morg. Pharma Online, 2:808-817, 2011a.

[7] Biswas G, Sarkar S, Acharya K. Hepatoprotective activity of the ethanolic extract of Astraeus hygrometricus (Pers.) Morg. Digest Journal of Nanomaterials and Biostructures, 6(2): 637-641, $2011 \mathrm{~b}$.

[8] Badalyan SM, Barkhudaryan A, Rapior S. Recent progress in Research on the Pharmaceutical Potential of Mushrooms and Prospects of Their Clinical Application (409 pp.). In: Agrawal DC, Dhanasekaran M, editors. Medicinal Mushrooms, Recent Progress in Research and Development. 1 ed. Springer Nature Singapore Pte Ltd., p. 1-71. ISBN 978-981-13-6381-8 and ISBN 978-981-136382-5 (e-Book). 2019. https://doi.org/10.1007/978-981-13-6382-5.

[9] Donatini B. Les vertus médicinales des champignons, Imprimerie Gamma à Trinqueux (51), M.I.F.s.a., Cormontreuil, France. 1999.

[10] [10] Poucheret P, Fons F, Rapior S. Biological and pharmacological activity of higher Fungi: 20-year retrospective analysis (A review, 196 references). Cryptogamy Mycology, 27(4):311-333, 2006.

[11] Okolo KO, Orisakwe OE, Siminialayi IM. Nephroprotective and antioxidant effects of king tuber oyster medicinal mushroom, Pleurotus tuberregium (Agaricomycetes), on carbon tetrachlorideinduced nephrotoxicity in male Sprague dawley rats. International Journal of Medicinal Mushrooms, 20(5):419-429, 2018.

[12] Valverde ME, Hernández-Pérez T, Paredes-López O. Edible mushrooms: improving human health and promoting quality life. International Journal of Microbiology, 37:63-87, 2015. https://doi.org/10.1155/2015/376387.

[13] Bandara AR, Rapior S, Bhat DJ, Kakumyan P, Chamyuang S, Xu J, Hyde KD. Polyporus umbellatus, an Edible-Medicinal Cultivated Mushroom with Multiple Developed Health-Care Products as Food, Medicine and Cosmetics: a review. Cryptogamie, Mycologie, 36(1): 3-42, 2015. https://doi.org/10.7872/crym.v36.iss1.2015.3.

[14] Chelela BL, Chacha M, Matemu A. Antibacterial and antifungal activities of selected wild mushrooms from Southern Highlands of Tanzania. American Journal of Research Communication, 2(9):58$68,2014$.

[15] Iwalokun BA, Otunba AA, Olukoya DK. Comparative phytotechnical evaluation, antimicrobial and antioxidant properties of Pleurotus ostreatus. African Journal Biotechnology, 5:17321739, 2007.

[16] Tonjock RK, Mih A. Secondary metabolites of oil palm isolates of Ganoderma zonatum Murill. from Cameroon and their cytotoxicity against five human tumour cell lines. African Journal of Biotechnology, 10(42): 8440-8447, 2011.

[17] Waithaka PN, Gathuru EM, Githaiga BM, Onkoba KM. Antimicrobial activity of mushroom (Agaricus bisporus) and Fungal (Trametes Gibbosa) Extracts from Mushrooms and Fungi of Egerton Main Campus, Njoro Kenya. Journal of Biomedicinal Sciences, 6(3): 1-6, 2017. https://doi.org/10.1155/2015/376387/10.4172/2254609X.100063.

[18] Guissou KLM, Sanon E, Sankara Ph, Guinko S. La Mycothérapie au Burkina Faso: Etat des lieux et perspectives. Journal of Applied Biosciences, 79: 6896-6908, 2014.

[19] Oyetayo OV. Medicinal uses of mushrooms in Nigeria: Towards full and sustainable exploitation. African Journal of Traditional, Complementary and Alternative Medicines, 8(3): 267-74, 2011.

[20] Walleyn R, Rammeloo J. The poisonous and useful fungi of Africa south of Sahara: a literature survey. Meise, Belgium: Scripta Botanica Belgica, 10: 1-56, 1994.

[21] Boonsong S, Klaypradit W. Antioxidant activities of extracts from five edible mushrooms using different extractants. Agriculture and Natural Ressources, $\quad 50$ : $\quad 89-97, \quad 2016$. https://doi.org/10.1016/j.anres.2015.07.002.

[22] McFarland. The nephelometer: an instrument for estimating the numbers of bacteria in suspensions used for calculating the opsonic index for vaccines. Journal of the American Medical Association, 49: 1176-1178, 1907.

[23] Eloff JN. A sensitive and quick microplate method to determine the minimal inhibitory concentration of plant extracts for bacteria. Planta Medica, 64: 711-713, 1998.

[24] Maragesi SM, Nyamwisenda NT, Mwangomo D, Kidukuli A. In vitro antimicrobial activity and determination of essential Metal and
Ash Value Contents of Trichodesma zeylanicum. International Journal of Research in Pharmaceutical Sciences, 2: 417-424, 2013.

[25] Fonkui YT, Ikhile IM, Munganza MF, Fotsing DCM, Arderne C, Noundou SX, Krause MWR, Ndinteh TD, Njobeh BP. Synthesis, characterization and biological application of novel schiff bases of 2-(trifluoromethoxy) alanine. Journal of China Pharmaceutical Science, 27(5): 307-323, 2018.

[26] Ishaku LE, Botha FS, McGway LJ, Eloff JN. The antibacterial activity of extracts of nine plant species with good activity against Escherichia coli against five other bacteria and cytotoxicity of extract. BMC Complementary and Alternative Medicine, 17(133):110, 2017. https://doi.org/10.1186/12906-017-1645-z.

[27] Praptiwi, Raunsai M, Wulansari D, Fathoni A, Agusta A. Antibacterial and antioxidant activities of endophytic fungi extracts of medicinal plants from Central Sulawesi. Journal of Applied $\begin{array}{llll}\text { Pharmaceutical Science, } & \text { 8(8): } & 69-74, & \end{array}$ https://doi.org/10.7324/JAPS.2018.8811.

[28] Algiannis N, Kalpotzakis E, Mitaku S, Chinou IB (2001) Composition and Antimicrobial Activity of Essential Oils of Two Origanum Species, Journal of Agricultural and Food Chemistry, 40:4168-4170.

[29] Johnsy G, Kaviyarasan V. Preliminary phytochemical screening, antimicrobial and antioxidant activity of methanol and water extarcts of Lentinus sajor-caju. World Journal of Pharmacy and pharmaceutical sciences, 3(3): 149-1472, 2014.

[30] Reena RD, Kandagalla S, Krishnappa M. Exploring the ethnomycological potential of Lentinus squarrosulus Mont. Through GC-MS and chemoinformatics tools. Mycology, 1-12, 2019. https://doi.org/10.1080/21501203.2019.1707724.

[31] Hassan IAF, Zubaida KC, Khan I, Saleh AA. Comparative study of antibacterial activity of wood-decay fungi and antibiotics, Journal Bangladesh Pharmacological Society, 6: 14-17, 2011. ISSN: 19910088.

[32] Moradali MF, Mostafavi H, Hejaroude GA, Tehrani AS, Abbasi M, Ghods S. Investigation of potential antibacterial properties of methanol extracts from fungus Ganoderma applanatum. Chemotherapy, 52(5):241-244, 2006.

[33] Ofodile LN, Uma NU, Kokubun T, Grayer RJ, Ogundipe OT, Simmonds MS. Antimicrobial activity of some Ganoderma species. Phytotherapy Ressources, 19: 310-13, 2005.

[34] Smania AJ, Delle Monache F, Smania EFA, Cueno RS Antibacterial activity of steroidal compounds isolated from Ganoderma applanatum (Pers.) Pat. (Aphyllophoromycetidae) fruit body. International Journal of Medicinal Mushrooms, 1: 325-330, 1999.

[35] Subrata G, Gunjan B, Prakash P, Subhash CM, Krishnendu A Antimicrobial activities of basidiocarps of wild edible mushrooms of west Bengal, India. International Journal of PharmTech Research, 4(4): 1554-1560, 2012.

[36] Agada GOA, Chollom SC, Gotep JG, Gambo NN, Tyem AD, Okeke IO, Nwankiti OO, Okwori AEJ. Evaluation of antimicrobial potential of ethanolic leaf and stem bark extracts of Tamarindus indica. International Journal of Applied Microbiology and Science, 1: 26-34, 2012.

[37] Mohamed SB, Hafida H, Chahrazed B, Djamel EA. Evaluation of antibacterial Activity of some Medicinal Plants Extracts Commonly Used in Algerian Traditional Medicine against some Pathogenic Bacteria. Pharmacognosy Journal, 10: 507-12, 2018.

[38] Bisi-Johnson AM, Chikwelu LO, Babatunde BS, Eloff JN, Okoh IA. Antibacterial activity of crude extracts of some South African medicinal plants against multidrug resistant etiological agents of diarrhea. BMC Complementary and Alternative Medicine, 17(321): 1-9, 2017. 